\title{
GENETIC DIVERSITY OF TWO STINGLESS BEES, TRIGONA NIGERRIMA (CRESSON 1878) AND TRIGONA CORVINA (COCKERELL 1913), IN COFFEE DOMINATED LANDSCAPES IN SOUTHERN MEXICO
}

\author{
E. DE J. SOLÓRZANO-GORDILLO, N. V. CABRERA-MARÍN, J. MÉRIDA, R. VANDAME \& D. \\ SÁNCHEZ*
}

\author{
El Colegio de la Frontera Sur, Carretera Antiguo Aeropuerto Km 2.5. Tapachula, Chiapas, Mexico, CP 30700. * \\ dsanchez@ecosur.mx
}

Recibido: 19/06/2014; aceptado: 12/09/2014

\begin{abstract}
Solórzano-Gordillo, E. de J., Cabrera-Marín, N. V., Mérida, J., Vandame, R. \& Sánchez, D. 2015. Genetic diversity of two stingless bees, Trigona nigerrima (Cresson 1878) and Trigona corvina (Cockerell 1913), in coffee dominated landscapes in Southern Mexico. Acta Zoológica Mexicana (n. s.), 31(1): 74-79.
\end{abstract}

ABSTRACT. Stingless bees (Apidae, Meliponini) are key pollinators in natural and agricultural Pantropical environments. Current human activities, however, threaten their populations, making it urgent to assess their abundance and genetic status. By a population genetics approach, we calculated the genetic diversity and estimated the number of wild colonies of two stingless bee species, Trigona nigerrima (Cresson) and T. corvina (Cockerell) in southern Mexico. Allele richness ranged from 10 to 19 (mean $\pm \mathrm{SD}=14 \pm 3.5$ ) for both species. Expected heterozygosity ranged $0.88-0.93$ for $T$. corvina and $0.82-0.92$ for T. nigerrima. The estimated number of colonies estimated was 25 on average for $T$. corvina and 21 for T. nigerrima. According to our results populations of both species seem not to be in danger. We also show that genetic tools can be extremely useful for colony density estimation for stingless bees as it is for bumble bees and honey bees.

Keywords: Stingless bee, microsatellites, DNA, population genetics, meliponine, Trigona.

\section{INTRODUCTION}

Human population, and the amount of resources necessary to sustain it, is globally increasing. Food and housing are basic elements that demand space; therefore natural areas are incorporated into production chains to satisfy these and other necessities. As a consequence, populations of native organisms are locally reduced or might become extinct. Studies have revealed a decline in the diversity and abundance of insect pollinators in Europe (Biesmeijer et al. 2006) and America (Goulson et al. 2008, Cameron et al. 2011), partially driven by intensive agricultural practices (Freitas et al. 2009, Potts et al. 2010). Large extensions of land devoted to only a few crops seem to leave few resources to native insect pollinators to survive, since such management frequently results in habitat loss and
Solórzano-Gordillo, E. de J., Cabrera-Marín, N. V., Mérida, J., Vandame, R. \& Sánchez, D. 2015. Diversidad genética de dos especies de abejas sin aguijón, Trigona nigerrima (Cresson) y Trigona corvina (Cockerell) en paisajes cafetaleros del Sureste de México. Acta Zoológica Mexicana (n. s.), 31(1): 74-79.

RESUMEN. Las abejas sin aguijón (Apidae, Meliponini) son especies polinizadoras clave en ambientes pantropicales, tanto naturales como agrícolas. Las actividades humanas, sin embargo, ponen en riesgo sus poblaciones silvestres, lo que hace necesario que se conozcan cuanto antes su abundancia y su diversidad genética con fines de conservación. Mediante un enfoque de genética de poblaciones se calculó la diversidad genética y el número de colonias silvestres de dos especies de abejas sin aguijón, Trigona nigerrima y T. corvina, en el sur de México. Se encontró una riqueza alélica que varió de 10 a 19 (media $\pm \mathrm{DE}=14 \pm 3.5$ ). La heterocigosidad esperada fue de 0.88-0.93 para T. corvina y de 0.82-0.92 para T. nigerrima El número de colonias estimadas para $T$. corvina fue de 25 en promedio, y para $T$. nigerrima de 21. De acuerdo con nuestros resultados las poblaciones de ambas especies parecen no estar amenazadas. También se demuestra que las herramientas de genética de poblaciones son extremadamente útiles para la estimación de colonias en abejas sin aguijón, al igual que en otros himenópteros como los abejorros y la abeja melífera.

Palabras clave: Abejas sin aguijón, microsatélites, ADN, genética de poblaciones, meliponinos, Trigona.

pollution of the environment (Richards 2001, Carvell et al. 2006). A reduction in the populations of these species could actually have serious impacts on the world's economy (Kevan \& Phillips 2001, Klein et al. 2007), and more importantly, on world's food security (Gallai et al. 2009). Among insect pollinators, eusocial bees (Hymenoptera, Apidae) like honey bees (Aizen \& Harder 2009) and bumble bees (Hayo \& Adriaan 2006) are key in crop pollination. In addition, a growing body of information reveals the importance of stingless bees (Apidae, Meliponini) as pollinators in natural and agricultural environments (Heard 1999, Cauich et al. 2004, Del Sarto et al. 2005, Palma et al. 2008). Current human activities, however, threaten their populations, and though some species seem to be abundant, others do not, and more importantly, the genetic status for many of them remains unknown. In 
fact, a genetic approach would reveal critical information, not attainable by conventional ecological methods, about the viability status of populations, not mentioning genetic diversity. For example, several studies have evaluated the effect of beekeeping upon both genetic variability (Carvalho-Zilse et al. 2009) and maintenance of populations (Alves et al. 2010), while others have evaluated genetic variability and population structure of stingless bees (Costa et al. 2005, Francisco et al. 2006, Garcia Tavares et al. 2007, Hurtado-Burillo et al. 2013). Additionally, population genetics is a powerful tool to estimate colony density for the study of population dynamics (Cameron et al. 2004, Moritz et al. 2007, Kraus et al. 2008), a better alternative to find and count colonies in the field (Zayed 2009). Thus in this paper we investigated the genetic diversity and colony density of two stingless bee species, Trigona nigerrima (Cresson 1878) and T. corvina (Cockerell 1913) in rural areas in Chiapas, Mexico, by genotyping free foraging individuals. We chose these species because they are the dominant native social species in the study sites and are frequently found foraging in several species of plants, both cultivated and wild.

\section{METHODS AND MATERIALS}

Study site. Foragers were collected between February and April 2011 in four localities in Chiapas, Mexico (Fig 1). Shade coffee is the main crop in the region, though other plants like corn and timber are also cultivated. The majority of the farmers possess small pieces of land $(<$
3 ha), thus a highly patchy landscape is formed. Local agriculture practices are mostly human-labor based, with low input of agrochemicals. All these conditions seemingly support habitat diversity and provide a variety of resources to animal populations.

Sampling scheme. Specimens were collected between 9:00-13:00 hours using standard entomological nets. Species were collected in sufficient number to perform comparative genetic analyses only in some sites: T. corvina in Tzajalchen and Chijil, and T. nigerrima in Plan Ocosingo and Rancho Naranjo. Trigona species are known to recruit nest mates to profitable resources (Lindauer \& Kerr 1960, Nieh 2004, Sánchez et al. 2004), which could lead to an underestimation of allelic richness if foragers are analyzed. To avoid this, specimens were collected such that: 1) two to four foragers were collected where they were found in groups of more than ten individuals and, 2) they were collected in patches separated from each other by at least $500 \mathrm{~m}$. Foragers were sacrificed with ethyl acetate; one hind leg was removed from each collected specimen and placed in absolute ethanol for further storing at $-20^{\circ} \mathrm{C}$ and DNA extraction. The rest of the insect was kept in an entomological collection in ECOSUR, San Cristobal de las Casas, Chiapas.

Microsatellite analysis. DNA was extracted following the HotSHOT method (Truett et al. 2000). All foragers were genotyped at four microsatellite loci (T3-32, Tc3302, T4-171 and T8-40) following single locus routine PCR protocols (Kraus et al. 2008) to a final reaction volume of $5 \mu \mathrm{L}$. Microsatellite fragments were separated us-

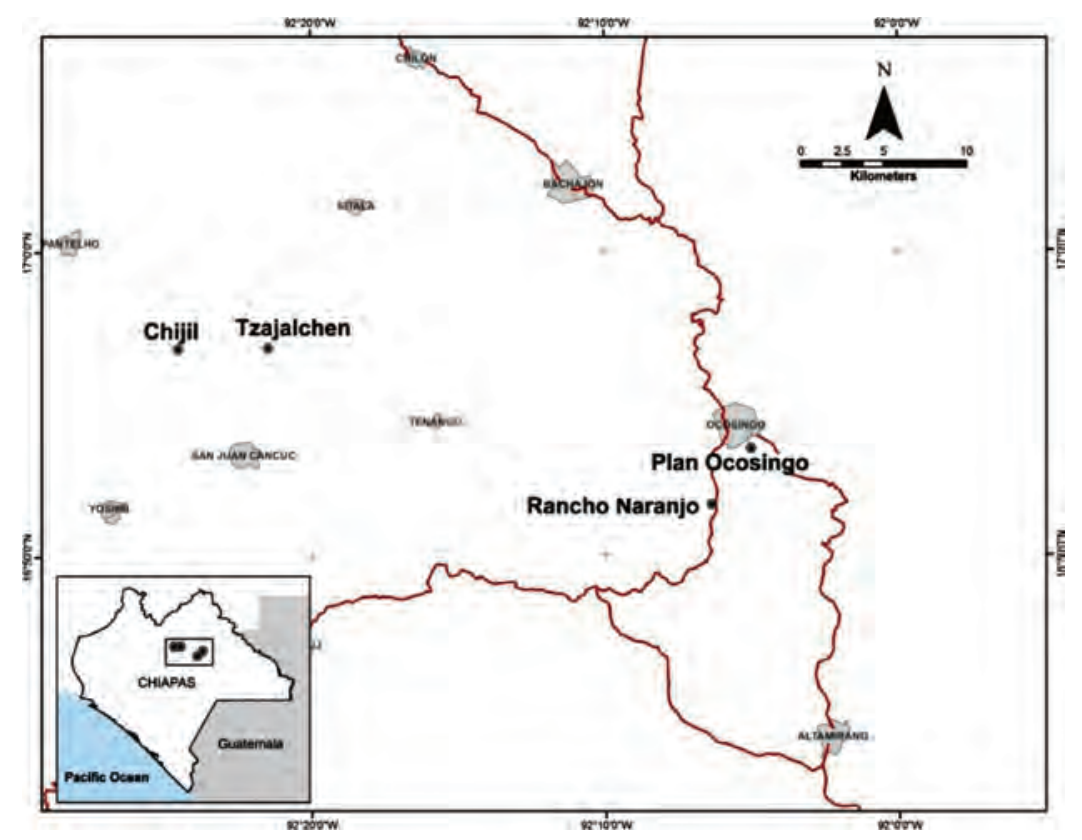

Figure 1. Location of study sites. 
ing a semiautomated LI-COR 4200 slab-gel sequencer (6\% denaturing polyacrylamide gels); fragment size was determined using the software SAGA MX (LI-COR Inc., US). Forward oligos were tagged with an M13(-29) sequence, which served as a priming site to a M13(-29) primer tagged with IRDYE800 (Schuelke 2000). In order to estimate amplification errors or allele miss-callings $10 \%$ of foragers were subjected to reamplification at all loci. All reamplifications gave identical results.

Analysis of genetic data. Screening of data for large allele dropout, null alleles and scoring errors was carried out using MicroChecker (Van Oosterhout et al. 2004). Departures from Hardy-Weinberg proportions of each loci, pairwise genotypic linkage disequilibrium, expected and observed heterozygosities, and tests for population differentiation were performed using GENEPOP v4.0 (Rousset 2008). Allelic richness was calculated with FSTAT v2.9.3.2 software (Goudet 2001), which was used to compare the genetic diversity between sites with a paired T-Students' test using S-Plus v6. Number of colonies in each site was estimated with COLONY v1.2 software (Wang 2004).

\section{RESULTS}

A total of 194 female individuals from the four sites were genotyped: ninety-eight $T$. nigerrima and ninety-six $T$. corvina individuals. Scoring errors, allele dropout and null alleles were not detected in any loci in any species; however the T8-40 locus in T. corvina from the two sites departed significantly from Hardy-Weinberg equilibrium, perhaps because primers were developed for other species (Hurtado-Burillo et al. 2013), thus it was removed from allelic richness comparisons. All loci in both species were not in significant linkage $(\mathrm{P}>0.05)$. Tables 1 and 2 show the expected and observed heterozygosity and the allelic richness per locus, population and species. Allelic richness was not significantly different between sites for both species ( $T$. corvina: $\mathrm{t}=3.05, \mathrm{df}=2, \mathrm{P}=0.09 ; \mathrm{T}$. nigerrima: $\mathrm{t}=2.54, \mathrm{df}=3, \mathrm{P}=0.09$ ) though genotypic differentiation between each pair of sites was highly significant in both species (T.corvina: $\mathrm{G}=46.48$, $\mathrm{df}=8, \mathrm{P}<$ 0.001; T nigerrima: $\mathrm{G}=143, \mathrm{df}=8, \mathrm{P}<0.001$ ). Number of colonies estimated for T. corvina was 26 and 24 for Rancho Naranjo and Plan Ocosingo sites, respectively. For T. nigerrima the numbers were lower, 20 and 22 for the Tzajalchen and the Chijil sites, respectively.

\section{DISCUSSION}

In spite that some of the sampling sites seemed to be more disturbed due to the presence of grasslands, we did not find any significant difference in the allelic richness in
Table 1. Genetic diversity parameters estimated for Trigona corvina. $\mathrm{N}_{\mathrm{T}}$ : Number of individuals genotyped at the corresponding locus, $\mathrm{N}_{\mathrm{A}}$ : Number of alleles, $A_{r}$ : Allelic richness, $H_{e}$ : Expected heterozygosity; $\mathrm{H}_{\mathrm{o}}$ : Observed heterozygosity *Locus excluded from the analysis of allelic diversity due to deviation from Hardy-Weinberg equilibrium.

\begin{tabular}{cccccc}
\hline \multicolumn{5}{c}{ Trigona corvina - Plan Ocosingo } \\
& $\mathrm{N}_{\mathrm{I}}$ & $\mathrm{N}_{\mathrm{A}}$ & $\mathrm{Ar}$ & $\mathrm{He}$ & $\mathrm{Ho}$ \\
T3-32 & 45 & 16 & 15.96 & 0.88 & 0.74 \\
Tc3-302 & 44 & 18 & 17.20 & 0.92 & 0.83 \\
T4-171 & 44 & 15 & 14.86 & 0.89 & 0.77 \\
T8-40* & 45 & 12 & 11.98 & 0.90 & 0.65 \\
Average & - & 15.2 & 15 & 0.89 & 0.74 \\
& \multicolumn{7}{c}{ Trigona corvina - Rancho Naranjo } & \\
& $\mathrm{N}_{\mathrm{I}}$ & $\mathrm{N}_{\mathrm{A}}$ & Ar & $\mathrm{He}$ & $\mathrm{Ho}$ \\
T3-32 & 39 & 12 & 12.00 & 0.93 & 0.89 \\
Tc3-302 & 41 & 16 & 15.95 & 0.88 & 0.86 \\
T4-171 & 44 & 13 & 12.75 & 0.92 & 0.80 \\
T8-40* & 46 & 15 & 14.51 & 0.90 & 0.67 \\
Average & - & 14 & 13.8 & 0.90 & 0.80 \\
\hline
\end{tabular}

Table 2. Genetic diversity parameters estimated for Trigona nigerrima. Column names as in Table 1.

\begin{tabular}{|c|c|c|c|c|c|}
\hline \multicolumn{6}{|c|}{ Trigona nigerrima - Chijil } \\
\hline & $\mathrm{N}_{\mathrm{I}}$ & $\mathrm{N}_{\mathrm{A}}$ & $\mathrm{Ar}$ & $\mathrm{He}$ & Ho \\
\hline T3-32 & 40 & 10 & 9.92 & 0.82 & 0.83 \\
\hline Tc3-302 & 44 & 20 & 19.60 & 0.92 & 0.93 \\
\hline $\mathrm{T} 4-171$ & 45 & 12 & 11.58 & 0.83 & 0.96 \\
\hline T8-40 & 43 & 14 & 13.71 & 0.90 & 0.79 \\
\hline Average & - & 14 & 13.7 & 0.86 & 0.86 \\
\hline \multicolumn{6}{|c|}{ Trigona nigerrima -Tzajalchen } \\
\hline & $\mathrm{N}_{\mathrm{I}}$ & $\mathrm{N}_{\mathrm{A}}$ & $\mathrm{Ar}$ & $\mathrm{He}$ & Ho \\
\hline T3-32 & 39 & 10 & 10.00 & 0.83 & 0.85 \\
\hline Tc3-302 & 42 & 18 & 17.75 & 0.91 & 0.93 \\
\hline T4-171 & 48 & 8 & 7.92 & 0.82 & 0.94 \\
\hline T8-40 & 48 & 10 & 10.00 & 0.89 & 0.85 \\
\hline Average & - & 11.5 & 11.4 & 0.86 & 0.89 \\
\hline
\end{tabular}

any of the Trigona species, thus at a regional level both species seem to be in similar conditions. Moreover, observed heterozygocity was high in all sites. We think that it is the low input of agrochemicals, and the presence of a mosaic of crops and trees that is formed due to rural activities, what helps maintaining populations with such high heterozygosity and allelic diversity, though future research should confirm this. Studies with other stingless bees show diverse results. For example, while Francisco et al. (2013) found heterozygosity values from 0.551 to 0.749 in Plebeia remota (Holmberg 1903) and Francini 
et al. (2009) from zero to 0.75 in Melipona interrupta manaosensis (Schwarz 1932); other authors as Borges et al. (2010) and Tavares et al. (2013) describe very low levels of observed heterozygosity in their study with Partamona helleri (Friese 1900) and M. quadrifasciata (Lepeletier 1836). In the study by May-Itzá et al. (2010) with M. yucatanica in Mexico and Guatemala very low levels of heterozygosity were also found. In these studies the low value of the observed heterozygosity can be explained by the swarming behavior of stingless bees, since the daughter colony is commonly founded near the original one, favoring endogamy. A weakness in all these studies is the sampling scheme: they collected directly from colonies and many samples were obtained from neighboring colonies. Studies by Cameron et al. (2004) and Kraus et al. (2008) involved sampling drones, massively grouped in congregations. They found far higher genetic diversity values, since drones were determined to come from as many as 40 colonies for Scaptotrigona mexicana (Guérin 1844) and 137 for T. collina (Smith 1857). This indicates that a number of colonies might not be sampled if colony surveying is the main sampling scheme, instead of genotyping free flying foragers or drones. It is important to emphasize how important to our approach of surveying free flying foragers is the fact that stingless bees are mainly single mated (Palmer et al. 2002, Paxton et al. 2003, Toth et al. 2004), since estimation of colonies using microsatellites is greatly far more accurate than for multiple mating species, like Apis spp. (Fuchs \& Moritz 1999), in which a large number of workers is necessary to estimate a queen's genotype with some accuracy, and thus colony density.

According to our data populations were genotypically different. We think that the short flight range of Trigona, in addition to forest fragments surrounded by a matrix of crops and villages and the presence of orographic discontinuities, contribute to explain the genotypic differences between sites; this has to be proven yet. We also were able to estimate colony density with our data, something that had not been done before with free flying workers of stingless bees. Though we did not survey exhaustively our sampling sites, we could estimate colony density as 0.2 to 0.26 nests/ha, since our sites corresponded to approximately 100 ha. Such density is similar to that described for other stingless bees in non disturbed sites (Slaa 2006). These densities also reflect that populations of these species seem not to be compromised. Therefore it is highly likely that the degree of patchiness and the actual quality of the patches in the study sites are not affecting bee populations at detectable levels. Hurtado-Burillo et al. (2014) compared the genetic richness of two Melipona species occurring in Mexico, M. colimana and $M$. beecheii, and found no significant differences in expected heterozygosity; moreover, these authors found no significant differences between the populations from deforested and conserved areas, with results similar to ours. However, as mentioned lines above, many lines of research arise to develop a more detailed view of the situation of stingless bees populations in this part of Mexico, but our results give the baseline for these studies.

Acknowledgements. We appreciate the help given by Agustín Méndez, Miguel Cigarroa and Miguel Guzmán during sampling. We also appreciate the kind comments made by the three anonymous reviewers that helped us to significantly improve this manuscript. This study was possible thanks to the support of SEP-CONACYT grant no. 128702 "Evolución de la Cleptobiosis en Lestrimelitta (Apidae, Meliponini)" and SEP-CONACYT grant no. 106043 "Land use effect on the conservation of bees' biodiversity"

\section{REFERENCES}

Aizen, M. A. \& Harder, L. D. 2009. The Global Stock of Domesticated Honey Bees Is Growing Slower Than Agricultural Demand for Pollination. Current Biology, 19: 915-918.

Alves, D. A., Imperatriz-Fonseca, V. L., Francoy, T. M., Santos-Filho, P. S., Billen, J. \& Wenseleers, T. 2010. Successful maintenance of a stingless bee population despite a severe genetic bottleneck. Conservation Genetics, 12: 647-658.

Biesmeijer, J. C., Roberts, S., Reemer, M., Ohlemuller, R., Edwards, M., Peeters, T., Schaffers, A., Potts, S., Kleukers, R., Thomas, C., Settele, J. \& Kunin W. 2006. Parallel declines in pollinators and insect-pollinated plants in Britain and the Netherlands. Science, 313: 351-354.

Borges, A. A., de Oliveira Campos, L. A., Salomao, T. M. \& Tavares, M. G. 2010. Genetic variability in five populations of Partamona helleri (Hymenoptera, Apidae) from Minas Gerais State, Brazil. Genetics and Molecular Biology, 33: 781-784.

Cameron, E. C., Franck, P. \& Oldroyd, B. P. 2004. Genetic structure of nest aggregations and drone congregations of the southeast Asian stingless bee Trigona collina. Molecular Ecology, 13: 23572364.

Cameron, S. A., Lozier, J. D., Strange, J. P., Koch, J. B., Cordes, N., Solter, L. F. \& Griswold, T. L. 2011. Patterns of widespread decline in North American bumble bees. Proceedings of the National Academy of Sciences, 108: 662-667.

Carvalho-Zilse, G. A., Costa-Pinto, M. F., Nunes-Silva, C. G. \& Kerr, W. E. 2009. Does beekeeping reduce genetic variability in Melipona scutellaris (Apidae, Meliponini)? Genetics and Molecular Research, 8: 758-765.

Carvell, C., Roy, D. B., Smart, S. M., Pywell, R. F., Preston, C. D. \& Goulson, D. 2006. Declines in forage availability for bumblebees at a national scale. Biological Conservation, 132: 481-489.

Cauich, O., Quezada-Euán, J. J. G., Macias-Macias, J. O., ReyesOregel, V., Medina-Peralta, S. \& Parra-Tabla, V. 2004. Behavior and pollination efficiency of Nannotrigona perilampoides (Hymenoptera: Meliponini) on greenhouse tomatoes (Lycopersicon esculentum) in subtropical Mexico. Journal of Economic Entomology, 97: 475-481.

Costa, R. G., Tavares, M. G., Dias, L. A. \& Campos, L. A. 2005. Isoenzyme variation in Melipona rufiventris (Hymenoptera: Api- 
dae, Meliponina) in Minas Gerais State, Brazil. Biochemical Genetics, 43: 49-58.

Del Sarto, M. C., Peruquetti, R. C. \& Campos, L. A. 2005. Evaluation of the neotropical stingless bee Melipona quadrifasciata (Hymenoptera: Apidae) as pollinator of greenhouse tomatoes. Journal of Economic Entomology, 98: 260-266.

Francini, I. B., Sousa, A. C. B., Sforça, D. A., Costa-Pinto, M. F. F., Campos, T., Nunes-Silva, C. G., Zucchi, M. I., Souza, A. P. \& Carvalho-Zilse, G. A. 2009. Isolation and characterization of microsatellite loci in the stingless bee Melipona interrupta manaosensis (Apidae: Meliponini). Conservation Genetics Resources, 2: 27-30.

Francisco, F. d. O., Brito, R. M. \& Arias, M. C. 2006. Alelle number and heterozigosity for microsatellite loci in different stingless bee species (Hymenoptera: Apidae, Meliponini). Neotropical Entomology, 35: 638-643.

Francisco, F. d. O., Santiago, L. R. \& Arias, M. C. 2013. Molecular genetic diversity in populations of the stingless bee Plebeia remota: A case study. Genetics and Molecular Biology, 36: 118-123.

Freitas, B. M., Imperatriz-Fonseca, V. L., Medina, L. M., Kleinert, A. d. M. P., Galetto, L., Nates-Parra, G.\& Quezada-Euán, J. J. G. 2009. Diversity, threats and conservation of native bees in the Neotropics. Apidologie, 40: 332-346.

Fuchs, S. \& Moritz, R. F. A. 1999. Evolution of extreme polyandry in the honeybee Apis mellifera L. Behavioral Ecology and Sociobiology, 45: 269-275.

Gallai, N., Salles, J.-M., Settele, J. \& Vaissière, B. E. 2009. Economic valuation of the vulnerability of world agriculture confronted with pollinator decline. Ecological Economics, 68: 810-821.

Garcia Tavares, M., dos Santos Dias, L. A., Arantes Borges, A. I., Meneses Lopes, D., Pereira Busse, A. L. H., Guimarães Costa, R., Fernandes Salomão, T. M. \& Oliveira Campos, L. A. d. 2007. Genetic divergence between populations of the stingless bee uruc $\square \mathrm{u}$ amarela (Melipona rufiventris group, Hymenoptera, Meliponini): Is there a new Melipona species in the Brazilian state of Minas Gerais? Genetics and Molecular Biology, 30: 667-675.

Goudet, J. 2001. FSTAT, a program to estimate and test gene diversities and fixation indices (version 2.9.3.2). Available from http:// www2.unil.ch/popgen/softwares/fstat.htm.

Goulson, D., Lye, G.\& Darvill, B. 2008. Decline and conservation of bumble bees. Annual Review of Entomology, 53: 191-208.

Hayo, H. W. V., \& Adriaan, v. D. 2006. A century of advances in bumblebee domestication and the economic and environmental aspects of its commercialization for pollination. Apidologie, 37: 421-451.

Heard, T. A. 1999. The role of stingless bees in crop pollination. Annual Review of Entomology, 44: 183-206.

Hurtado-Burillo, M., Martínez, J., May-Itza, W. d. J., QuezadaEuán, J. J. G. \& De la Rúa, P. 2014. Estudio de microsatélites en las abejas sin aguijón Melipona colimana y M. beecheii de Mesoamérica. Archivos de Zootecnia, 63: 145-151.

Hurtado-Burillo, M., Ruiz, C., de Jesús May-Itzá, W., QuezadaEúan, J. J. G. \& De la Rúa, P. 2013. Barcoding stingless bees: genetic diversity of the economically important genus Scaptotrigona in Mesoamerica. Apidologie, 44: 1-10.

Kevan, P. G. \& Phillips, T. P. 2001. The economic impacts of pollinator declines: An approach to assessing the consequences. Conservation Ecology, 5: 211-230.

Klein, A. M., Vaissiere, B. E., Cane, J. H., Steffan-Dewenter, I., Cunningham, S. A., Kremen, C. \& Tscharntke, T. 2007. Importance of pollinators in changing landscapes for world crops.
Proceedings of the Royal Society B: Biological Sciences, 274: 303-313.

Kraus, F., Weinhold, S. \& Moritz, R. 2008. Genetic structure of drone congregations of the stingless bee Scaptotrigona mexicana. Insectes Sociaux, 55: 22-27.

Lindauer, M. \& Kerr, W. E. 1960. Communication between the workers of stingless bees. Bee World, 41: 29-41, 65-71.

May-Itzá, W. d. J., Quezada-Euán, J. J. G., Medina Medina, L. A., Enríquez, E. \& De la Rúa, P. 2010. Morphometric and genetic differentiation in isolated populations of the endangered Mesoamerican stingless bee Melipona yucatanica (Hymenoptera: Apoidea) suggest the existence of a two species complex. Conservation Genetics, 11: 2079-2084.

Moritz, R. F. A., Dietemann, V. \& Crewe, R. 2007. Determining colony densities in wild honeybee populations (Apis mellifera) with linked microsatellite DNA markers. Journal of Insect Conservation, 12: 455-459.

Nieh, J. C. 2004. Recruitment communication in stingless bees (Hymenoptera, Apidae, Meliponini). Apidologie, 35: 159-182.

Palma, G., Quezada-Euán, J. J. G., Reyes-Oregel, V., Meléndez, V. \& Moo-Valle, H. 2008. Production of greenhouse tomatoes (Lycopersicon esculentum) using Nannotrigona perilampoides, Bombus impatiens and mechanical vibration (Hym.: Apoidea). Journal of Applied Entomology, 132: 79-85.

Palmer, K. A., Oldroyd, B. P., Quezada-Euán, J. J. G., Paxton, R. J. \& May-Itza W de, J. 2002. Paternity frequency and maternity of males in some stingless bee species. Molecular Ecology, 11: 2107-2113.

Paxton, R. J., Bego, L. R., Shah, M. M. \& Mateus, S. 2003. Low mating frequency of queens in the stingless bee Scaptotrigona postica and worker maternity of males. Behavioral Ecology and Sociobiology, 53: 174-181.

Potts, S., Biesmeijer, J., Kremen, C., Neumann, P., Schweiger, O. \& Kunin, W. 2010. Global pollinator declines: trends, impacts and drivers. Trends in Ecology \& Evolution, 25: 345-353.

Richards, A. J. 2001. Does low biodiversity resulting from modern agricultural practice affect crop pollination and yield? Annals of Botany, 88: 165-172.

Rousset, F. 2008. Genepop'007: a complete reimplementation of the Genepop software for Windows and Linux. Molecular Ecology Resources, 8: 103-106.

Sánchez, D., Nieh, J. C., Hénaut, Y., Cruz, L. \& Vandame, R. 2004. High precision during food recruitment of experienced (reactivated) foragers in the stingless bee Scaptotrigona mexicana (Apidae, Meliponini). Naturwissenschaften, 91: 346-349.

Schuelke, M. 2000. An economic method for the fluorescent labeling of PCR fragments. Nature Biotechnology, 18: 233-234.

Slaa, E. J. 2006. Population dynamics of a stingless bee community in the seasonal dry lowlands of Costa Rica. Insectes Sociaux, 53: 70-79.

Tavares, M. G., Pietrani, N. T., de Castro Durvale, M., Resende, H. C. \& de Oliveira Campos, L. A. 2013. Genetic divergence between Melipona quadrifasciata Lepeletier (Hymenoptera, Apidae) populations. Genetics and Molecular Biology, 36: 111-117.

Toth, E., Queller, D. C., Dollin, A. \& Strassmann, J. E. 2004. Conflict over male parentage in stingless bees. Insectes Sociaux, 51: $1-11$.

Truett, G., Heeger, P., Mynatt, R., Truett, A., Walker, J. \& Warman, M. 2000. Preparation of PCR-quality mouse genomic DNA with hot sodium hydroxide and tris (HotSHOT). Biotechniques, 29: 52-54. 
Van Oosterhout, C., Hutchinson, W. F., Wills, D. P. M. \& Shipley, P. 2004. MICRO-CHECKER: software for identifying and correcting genotyping errors in microsatellite data. Molecular Ecology Notes, 4: 535-538
Wang, J. 2004. Sibship reconstruction from genetic data with typing errors. Genetics, 166: 1963-1979.

Zayed, A. 2009. Bee genetics and conservation. Apidologie, 40: 237262. 